NBER WORKING PAPER SERIES

\title{
CAUSING PROBLEMS? \\ THE WTO REVIEW OF CAUSATION AND \\ INJURY ATTRIBUTION IN U.S. SECTION 201 CASES
}

\author{
Douglas A. Irwin \\ Working Paper 9815 \\ http://www.nber.org/papers/w9815 \\ NATIONAL BUREAU OF ECONOMIC RESEARCH \\ 1050 Massachusetts Avenue \\ Cambridge, MA 02138 \\ July 2003
}

This paper was prepared for the Dartmouth-Tuck Forum on International Trade and Business conference on Managing Global Trade: The WTO, Trade Remedies and Dispute Settlement," Washington, D.C., May 16-17, 2003. I wish to thank Chad Bown, Robert Feinberg, the late Robert Hudec, and Petros Mavroidis for very helpful comments. The views expressed herein are those of the authors and not necessarily those of the National Bureau of Economic Research

(C)2003 by Douglas A. Irwin. All rights reserved. Short sections of text not to exceed two paragraphs, may be quoted without explicit permission provided that full credit including (C) notice, is given to the source. 
Causing Problems? The WTO Review of Causation and Injury Attribution in U.S. Section 201 Cases

Douglas A. Irwin

NBER Working Paper No. 9815

July 2003

JEL No. F1, K2

\begin{abstract}
U.S. safeguard actions have run into problems with the WTO's Panel and Appellate Body reviews for failing to ensure that injury caused by non-import factors is not attributed to imports. This paper reviews the subtle legal and economic differences between U.S. trade law (Section 201) and the WTO's Agreement on Safeguards on the non-attribution issue. The paper then resurrects the Kelly (1988) method of attributing injury to various factors as a potential method by which the ITC can ensure that future decisions conform with the Safeguards Agreement. The method is shown to yield results that are consistent with recent ITC safeguard decisions.
\end{abstract}

Douglas A. Irwin

Department of Economics

Dartmouth College

Hanover, NH 03755

and NBER

douglas.irwin@dartmouth.edu 


\section{Causing Problems? \\ The WTO Review of Causation and Injury Attribution in U.S. Section 201 Cases}

\section{Introduction}

Since the Uruguay Round Agreements went into effect in 1995, the U.S. International Trade Commission (ITC) has rendered six affirmative decisions on cases filed under Section 201 of the Trade Act of 1974, the so-called "escape clause." (See Table 1.) Four of these six decisions have been challenged in the World Trade Organization (WTO) for violating the Agreement on Safeguards reached in the Uruguay Round. In each instance, the WTO dispute settlement process has found some part of the ITC's decision inconsistent with U.S. obligations under that agreement. As a result, in several cases the trade remedy was abandoned or significantly modified.

This judicial review of ITC practice raises important legal and political questions about the conformity of U.S. trade law and practice with WTO obligations. Although the simplest solution is for the ITC to bring its safeguard determinations into conformity with WTO obligations, the method for doing so is not entirely clear and such an adjustment may be difficult if the WTO requirements differ significantly from U.S. law. If future ITC decisions do not conform to the WTO requirements, those safeguard actions are also likely to be challenged. In that case, U.S. policymakers are given the difficult choice of abandoning safeguard remedies, a risky path to take given the political attachment of the Congress to the integrity of U.S. trade law, or ignoring dispute settlement decisions, thereby undermining the WTO system. ${ }^{1}$

This is the broad setting for this paper's examination of one of the narrow issues upon

${ }^{1}$ Furthermore, if policymakers wish to shift the use of trade remedies from antidumping to safeguards actions, this task is made more difficult to the extent that the WTO agreements create legal obstacles to the use of safeguard measures. See Bown (2002). 
which the ITC has had difficulty with the WTO. Under the Agreement on Safeguards, the ITC is required to ensure that increased imports are a contributing cause of serious injury and that injury resulting from factors unrelated to increased imports is not attributed to imports. WTO panel and Appellate Body reports have repeatedly found that the ITC has failed to ensure that non-import-related injury is not attributed to imports, but have not indicated how the ITC should comply with this provision.

This paper begins by examining the subtle differences between the legal requirements of non-attribution in safeguard actions under U.S. trade law (Section 201 of the Trade Act of 1974) and in the WTO Agreement on Safeguards. The paper investigates how these differences have played out in the dispute resolution process in several recent U.S. safeguard actions. The paper then resurrects the Kelly (1988) method of attributing injury to various factors relating to changes in supply, demand, and imports, and applies the method to recent safeguard cases (Wheat Gluten, Lamb, Line Pipe, Wire Rod, and Steel). The results demonstrate how the ITC could use this approach to comply with the WTO requirements without really compromising the results of its decision-making process.

\section{The Legal Framework for Safeguard Actions}

Safeguard provisions permit a country to raise trade barriers that are otherwise bound in trade agreements in order to provide short-term protection to an industry harmed by foreign competition. Such provisions have been an integral part of U.S. trade policy ever since an executive order in 1945 required their inclusion in trade agreements signed by the United States. That order was in response to pressure from Congress to ensure that, as tariffs came down as a 
result of trade agreements, provision was made to provide temporary assistance to industries adversely affected by imports. ${ }^{2}$

Section 201 of the Trade Act of 1974 sets out the conditions under which safeguard actions can be implemented in the United States. Under Section 201, after receiving a petition from a domestic industry, the ITC is required to conduct an investigation "to determine whether an article is being imported into the United States in such increased quantities as to be a substantial cause of serious injury, or the threat thereof, to the domestic industry producing an article like or directly competitive with the imported article."3

The key phrases here are "substantial cause" and "serious injury." Serious injury is defined as "a significant overall impairment in the position of a domestic industry." In determining whether serious injury has taken place, the statute directs the ITC to "take into account all economic factors which it considers relevant," such as the significant idling of productive facilities in the industry (the closing of plants or the underutilization of production capacity), the inability of a significant number of firms to operate at a reasonable level of profit, and significant unemployment or underemployment within the industry. ${ }^{4}$ The presence or

${ }^{2}$ Hoekman and Kostecki (2001, p. 303) argue that "Safeguard provisions are often critical to the existence and operation of trade-liberalizing agreements, as they function as both insurance mechanisms and safety valves. They provide governments with the means to renege on specific liberalization commitments - subject to certain conditions - should the need for this arise (safety valves). Without them governments may refrain from signing an agreement that reduces protection substantially (insurance motive)." For a more critical view of safeguards, see Sykes (1991).

3 All quotations to U.S. law are from the compilation in U.S. House of Representatives (1997).

${ }^{4}$ With respect to the "threat" of serious injury, the statute points to such factors as a decline in sales or market share, a higher and growing inventory (whether maintained by domestic producers, importers, wholesalers, or retailers), and a downward trend in production, 
absence of any single factor is not necessarily decisive in determining whether the "serious injury" threshold is met.

A "substantial cause" is defined as "a cause which is important and not less than any other cause." While increased imports may be a source of injury to a domestic industry, imports must be a more (or no less) important source of injury than any other factor for it to constitute a "substantial cause" and thereby permit trade relief. In determining whether imports are a substantial cause of injury, the ITC is instructed by the statute to look for an increase in imports (either actual or relative to domestic production) and a decline in the proportion of the domestic market supplied by domestic producers. The legislative history of Section 201 suggests that other sources of injury include "changes in technology or in consumer tastes, domestic competition from substitute products, plant obsolescence, or poor management." If such factors are found to be a more important cause of injury than increased imports, a negative determination would be appropriate. ${ }^{5}$ The statute, however, provides no indication of how the ITC is to determine whether an increase in imports is a more important source of injury than any of other source.

Largely at the insistence of the United States, safeguard provisions have also been included in multilateral trade agreements. Article XIX of the General Agreement on Tariffs and

profits, wages, productivity or employment (or increasing underemployment) in the domestic industry concerned.

5 See U.S. International Trade Commission (1999a, p. I-21, footnote 106). The statute also says that the ITC should "consider the condition of the domestic industry over the course of the relevant business cycle, but may not aggregate the causes of declining demand associated with a recession or economic downturn in the United States economy into a single cause of serious injury or threat of injury." This provision does not seem relevant for cases filed between 1995 and 2001, a period when there was no general economic downturn. 
Trade (GATT) is a broadly-written provision that permits countries to suspend their obligations under the agreement and impose temporary trade barriers. The Agreement on Safeguards, reached during the Uruguay Round negotiations, sets out more specific standards than Article XIX for the application of safeguard measures. To a large extent, the language in the Safeguards Agreement mirrors that in Section 201. Under Article 2.1 of the Safeguards Agreement, for example, WTO members "may apply a safeguard measure to a product only if that Member has determined, pursuant to the provisions set out below, that such product is being imported into its territory in such increased quantities, absolute or relative to domestic production, and under such conditions as to cause or threaten to cause serious injury to the domestic industry that produces like or directly competitive products." Similarly, Article 3.1 requires that national authorities undertake an investigation to determine if imports have caused serious injury before imposing a safeguard measure and Article 4.1(a) defines "serious injury" as "a significant overall impairment in the position of a domestic industry."

Given the similar language in both Section 201 and the Safeguards Agreement, it is difficult to see how differences in interpretation between the ITC and the WTO could exist over such actions. One hitch, however, has been the somewhat different language in Article 4.2(b) of the Safeguard Agreement. According to this subsection, a positive finding of serious injury shall

${ }^{6}$ Article 4.2(a) is also similar to Section 201 in this regard: "In the investigation to determine whether increased imports have caused or are threatening to cause serious injury to a domestic industry under the terms of this Agreement, the competent authorities shall evaluate all relevant factors of an objective and quantifiable nature having a bearing on the situation of that industry, in particular, the rate and amount of the increase in imports of the product concerned in absolute and relative terms, the share of the domestic market taken by increased imports, changes in the level of sales, production, productivity, capacity utilization, profits and losses, and employment." 
not be made

"unless this investigation demonstrates, on the basis of objective evidence, the existence of the causal link between increased imports of the product concerned and serious injury or threat thereof. When factors other than increased imports are causing injury to the domestic industry at the same time, such injury shall not be attributed to increased imports."

The "causal link" requires objective evidence that harm to an industry coincides with a period of increased imports or import penetration. This causation standard has occasionally been problematic, but a more persistent source of difficulty has been the non-attribution standard in the last sentence - that other sources of injury shall not be attributed to increased imports.

\section{Injury Attribution in Recent ITC Decisions}

Most ITC determinations of "increased imports" and "serious injury" are relatively straightforward factual matters. In most - but not all - Section 201 cases, the domestic industry has suffered from some demonstrable economic distress and import penetration has increased markedly. ${ }^{7}$ Both the ITC and WTO panels agree that the coincidence of a higher level of imports and a lower level of domestic activity usually constitutes sufficient evidence that imports have caused injury. ${ }^{8}$

7 That this is not always the case is demonstrated by the ITC's rejection of two Section 201 petitions in 2000. In the Crabmeat case, the import market share went from 26.8 percent in 1995 to 70.1 percent in 1999, yet the divided Commission determined that the industry did not suffer from "serious injury" because it failed to find any significant overall impairment in the position of the domestic industry.

${ }^{8}$ For example, the Panel in the Wheat Gluten case agreed with the ITC approach in that "a coincidence in the movements in imports and the movements in injury factors would ordinarily tend to support a finding of causation." WTO (2000), para 8.95. See Kaplan (1991) for a discussion of the methods by which the ITC determines that import "cause" injury in antidumping and countervailing duty cases. 
The attribution of injury clause of the Safeguards Agreement requires the ITC to do something that it should have been doing under Section 201 anyway, but may have been doing only in a pro forma way. Section 201 directs the ITC to make a "substantial cause" determination, i.e., a finding that imports are "a cause which is important and not less than any other cause" in injuring the domestic industry. Article 4.2 (b) requires that injury attributed to factors other than imports not be attributed to imports. The U.S. statute requires that the various sources of injury be rank ordered, which implies that they must be separated. The WTO obligation does not require a rank ordering of sources of injury, but does require that the sources of injury be separated. The Safeguards Agreement does not require that imports be the most important cause of injury, just that the injury caused by other factors not be attributed to imports. Thus, the WTO standards for safeguard actions appear to be less stringent than those of Section 201.

Unfortunately for the ITC, the Commission has been very loose in its interpretation of "substantial cause" in the past, and now it is being challenged in the WTO on the non-attribution issue. This problem can be illustrated by examining ITC decision-making in four recent cases contested before the WTO: Wheat Gluten, Lamb Meat, Line Pipe, and Steel. ${ }^{9}$

In Wheat Gluten, the Commission (1998, p. I-16) wrote: "We reviewed carefully the alternative causes of injury suggested by the parties and other possible causes, and have concluded that increased imports are both an important cause of serious injury and a cause that is

9 Another Section 201 case in which trade remedies were applied is Certain Steel Wire Rod. However, a large share of imports came from Canada and Mexico, which were excluded from the safeguard action because they are members of NAFTA. The remaining suppliers were relatively small and did not contest the measure before the WTO. 
greater than any other cause." Several paragraphs then gave the reasoning behind the judgment that the other factors, such as developments in co-product (wheat starch) market adversely affecting domestic producers or a rise in the cost of raw materials (wheat flour), were not as important as imports.

In Lamb, the Commission described the coincidence of the declining economic condition of the industry and the rise in imports. "As required by the statute," the ITC (1999a, p. I-24) noted, "we considered whether any other cause might be a more important cause of the threat of serious injury than increased imports." The leading candidate as an alternative source of injury was the termination of federal government subsidies to lamb and sheep farmers under the National Wool Act of 1954. In 1993, Congress enacted legislation phasing out the support payments in 1994 and 1995. The ITC had "no doubt" that the loss of government financial support hurt lamb growers, but maintained that this was a "less important cause" of injury than imports (p. I-25). The precise basis for this judgment was not made clear. The ITC also looked at competition from other meat products, higher costs of production, and the lack of an effective marketing program as other possible causes of injury, but in each case ruled that they were less important factors than increased imports.

In Line Pipe, the Commission examined as an alternative source of injury the decline in demand for line pipe due to a reduction in oil and natural gas drilling and production activities. Five of six commissioners argued that there was "no question that such a substantial decline in demand contributed to the serious injury experienced by the domestic industry" but that they were "not persuaded" that it was "a greater contributing factor to the industry's serious injury than the imports" since the decline in demand would not explain the dramatic fall in market 
share held by domestic producers (1999b, p. I-28). Therefore, increased imports were judged "as great or greater" a factor as declining demand in producing injury (p. I-30). However, a dissenting commissioner argued that the industry was not seriously injured, nor was threatened with serious injury, but that had the domestic industry been judged to suffer serious injury, the most important cause of the injury would have been the decline in demand for welded pipe in the oil and gas industry.

The Steel safeguard cases involved 33 separate product categories in which the ITC ruled affirmatively in 16 . The focus here will be on the most important category, certain carbon and alloy flat-rolled products, including slab, hot-rolled, and cold-rolled bar. The Commission considered declining domestic demand, intra-industry competition, domestic capacity increases, and other factors as non-import sources of injury. The ITC (2001b, p. 59ff) ruled that the decline in demand came too late in the period of investigation to be a more important cause of injury than imports and that the intra-industry competition from mini-mills was a constant factor throughout the period. In addition, the expansion of domestic capacity, "while likely playing a role in the price declines that helped cause injury, was not an important cause of serious injury to the domestic industry equal to or greater than the injury cause by increased imports" because these capacity increases did not "lead prices downward, and wrest market share from imports."

Thus, from this brief examination of recent cases, it appears that the ITC essentially makes an informed but ultimately qualitative judgment call about the relative importance of various possible sources of injury. The determinations are not made with any explicit method, but a loose if reasoned sense among the Commissioners that the various factors causing injury carry the weight they do. The determinations vary in the depth and persuasiveness of the 
analysis of "substantial cause." Some rulings seem arbitrary and simply based on assertions (such as Lamb) while others are carefully considered and argued. None of them are based on any quantitative analysis and rarely has the ITC faced scrutiny or been forced to defend its decision-making process to other bodies.

In each of these cases, a trade remedy was imposed. In each case, the country or countries principally affected by the safeguard action contested the case in the WTO dispute settlement mechanism: the European Union in the case of wheat gluten, Australia and New Zealand in the case of lamb meat, Korea in the case of line pipe, and the European Union and others in the case of steel. Among the many complaints made by each of these countries was the allegation that the United States violated Article 4.2(b) of the Safeguards Agreement in not ensuring that injury caused by factors other than imports had not been attributed to imports.

\section{WTO Review of ITC Attribution Determinations}

In each of these cases, WTO Panels have upheld many aspects of ITC decision-making, but have had problems with the way in which the ITC attributed injury to imports and other factors. In the case of Wheat Gluten, for example, the Panel ruled that the ITC's serious injury determination was not inconsistent with Article 4.2(a). Furthermore, the causation standard was met because an upward trend in imports coincided with a downward trend in injury factors. However, the Panel held that the ITC violated Article 4.2(b) in not ensuring that injury cause by other factors was not attributed to imports. In doing so, the Panel put forth a particular interpretation of the Safeguard Agreement in which Members must not only separate, but also essentially rank order injury factors much like Section 201. 
The Panel noted that "Article 4.2(a) and (b) require a Member: (i) to demonstrate the existence of the causal link between increased imports and serious injury; and (ii) not to attribute injury being cause by other factors to the domestic industry at the same time to increased imports." The Panel argued that, "read together, these two propositions require that a Member demonstrate that the increased imports, under the conditions extant in the marketplace, in and of $\underline{\text { themselves, }}$ cause serious injury" (para 8.138). In other words, simply demonstrating that imports had increased and that injury had occurred was insufficient. If there are multiple causes of injury, then imports alone, independent of other factors, must be capable of causing injury that meets the threshold of "serious" as defined in the Agreement.

The Panel concluded that "the USITC's causation analysis does not ensure that imports, in and of themselves, are sufficient to cause serious injury to the domestic industry once injury caused by other factors is not attributed to imports" (para. 8.152). It could be the case, the Panel argued, that after deducting the injury due to other factors "any remaining injury caused by increased imports may not reach the threshold of serious injury" (para 8.143). While the ITC suggested that increased capacity investment by domestic producers could have been a source of injury, the Panel noted that "we see no indication in the USITC Report that imports were not also held responsible for the injury caused by this factor" (para 8.151).

The Panel was agnostic about how this attribution should be done, noting that the Safeguard Agreement does not impose

"any particular method for assessing whether any factors other than import are causing injury to its domestic market at the same time as imports, or how to go about ensuring that injury attributable to other factors is not attributed to imports. The United States remains free to choose a method for making this assessment and ensuring nonattribution" (para 8.140). 
The Panel also noted that a precise calculation of the different sources of injury was not mandated:

"A Member is not necessarily required to quantify, on an individual basis, the precise extent of 'injury' caused by each other possible factor. However, a Member must conduct an examination that ensures that any injury caused by such other factors is not attributed to increased imports." (Para 8.142)

The Wheat Gluten Panel's interpretation would have pushed the WTO requirement for safeguard actions beyond the standard in U.S. law under Section 201. A hypothetical example illustrates the issues involved. Suppose an industry has been judged to suffer "serious injury" and that imports are responsible for 40 percent of the injury and the remaining 60 percent is divided among two other factors. Then imports are a "substantial" cause - the most important cause - of injury. This meets the requirements of Section 201, of separating and rank ordering the causes of serious injury, and the ITC is done. But the Panel maintained that import alone must be capable of injury that meets the threshold of "serious." Thus, in the Panel's view, after taking way 60 percent of injury cause by other factors, the remaining 40 percent of injury attributed to imports must be significant enough to meet the "serious injury" threshold. This would have pushed the WTO standard from one that appears to be less burdensome than Section 201 to one that is more burdensome.

In its review of Wheat Gluten, however, the Appellate Body rejected the Panel's view that imports alone must be capable of causing serious injury. According to the AB report, "the need to distinguish between the effects caused by increased imports and the effects caused by other factors does not necessarily imply, as the Panel said, that increased imports on their own must be capable of causing serious injury, nor that injury caused by other factors must be excluded from the determination of serious injury" (para 70). They noted that Article 4.2(a) 
states that, in making the "serious injury" determination, the competent authorities "shall evaluate all relevant factors ... having a bearing on the situation in that industry." The AB noted that these factors relate both to imports specifically and overall situation generally and that "the language of the provision does not distinguish between, or attach special importance or preference to, any of the listed factors" (para. 72).

To further support its reasoning, the AB pointed to Article 2.1 of the Safeguards Agreement, which states that safeguard measures may be imposed when foreign products are being imported "under such conditions as to cause or threaten to cause serious injury to the domestic industry" (emphasis added). To the AB, the phrase "under such conditions" implies that "the competent authorities should determine whether the increase in imports, not alone, but in conjunction with the other relevant factors, cause serious injury" (para. 78). At the same time, the AB agreed with the Panel that the ITC had not adequately demonstrated that injury caused by increases in average capacity had not been attributed to increased imports. On this and other issues, the $\mathrm{AB}$ agreed with the panel that the ITC had erred in failing to ensure that the various causes of injury were not confounded..$^{10}$

The AB ruling restored the Safeguards Agreement to a weaker standard than Section 201 because the Agreement only requires the separation, and not the rank ordering, of different causes of injury. Considering another hypothetical example, if there were just two sources of injury, imports and factor $\mathrm{X}$ in which 10 percent of injury was attributed to imports and 90 percent to factor $X$, then this separation would satisfy the WTO obligations as long as there was

${ }^{10}$ For example, the Appellate Body found that the ITC had not adequately demonstrated that some forms of injury (increase in average capacity) had not been attributed to increased imports and therefore acted inconsistently with Article 4.2(b). 
serious injury (and causal role for imports, meaning an upward trend in imports coinciding with a downward trend in injury factors). However, it would not meet the "substantial cause" requirement of Section 201.

As a result of these decisions, the U.S. Trade Representative (USTR) requested that the ITC make its findings in the Wheat Gluten case conform to the findings of the WTO. In its report, the ITC (2001, p. 13) again explained the reasoning for its determination and maintained that it had not attributed injury from other sources to imports: "While the increase in industry capacity had some impact on the condition of the domestic industry, the available data do not indicated that it had a significant effect on industry performance, and we do not attribute the modest impact of the capacity increase to increased imports." The ITC essentially restated its qualitative assessment about injury attribution, which may be in fact accurate but was based on judgment and not on formal analysis.

The Panel in the Lamb case issued a finding very similar to that in Wheat Gluten because the $\mathrm{AB}$ had yet to rule on the Wheat Gluten case. As with Wheat Gluten, the AB ruling on Lamb reversed the Panel's interpretation on causation:

"In a situation where several factors are causing injury 'at the same time', a final determination about the injurious effects caused by increased imports can only be made if the injurious effects caused by all the different causal factors are distinguished and separated. Otherwise, any conclusion based exclusively on an assessment of only one of the causal factors - increased imports - rests on an uncertain foundation, because it assumes that the other causal factors are not causing the injury which has been ascribed to increased imports. The non-attribution language in Article 4.2(b) precludes such an assumption and, instead, requires that the competent authorities assess appropriately the injurious effects of the other factors, so that those effects may be disentangled from the injurious effects of the increased imports. In this way, the final determination rests, properly, on the genuine and substantial relationship of cause and effect between increased imports and serious injury." (para. 179).

The important requirement of Article 4.2(b) was to separate and distinguish the sources 
of injury. Yet the $\mathrm{AB}$ conceded that this leaves "unanswered many methodological questions relating to the non-attribution requirement found in the second sentence of Article 4.2(b) ... We emphasize that the method and approach WTO Members choose to carry out the process of separating the effects of increased imports and the effect of other causal factors is not specified in the Agreement on Safeguards" (para. 178, 180).

The AB also pointed to an important distinction between Section 201 and the Safeguards Agreement: "Although an examination of the relative causal importance of the different causal factors may satisfy the requirements of United States law, such an examination does not, for that reason, satisfy the requirement of the Agreement on Safeguards" (para 184). Once again the AB found fault with the ITC because it did "not explain the process by which the USITC separated the injurious effects of the different causal factors" (185). For example, in examining the loss of federal subsidies to the wool industry, the ITC "provides no insight into the nature and extent of the 'hurt' caused to the domestic industry by this factor" (para. 185).

The WTO Panel in the Line Pipe case also concerned itself with the issue of attribution because the injury resulting from declining demand in the oil and gas industry could have rivaled that of increased imports. The Panel stated:

"the methodology used in its analysis of the injury caused by the oil and gas decline has the objective (consistent with applicable U.S. law) of determining whether this factor is a more important cause of injury than the increased imports. We are not convinced that such a determination is enough to satisfy the requirements of Article 4.2(b)" (Para. 7.288).

Although the ITC recognized that the decline in the oil and gas industry injured the domestic line pipe industry, "it is not apparent from this analysis how, if at all, the ITC separated the injurious effects of the decline in the oil and gas industry from the injurious effects of the increased 
imports. The ITC's analysis provides no insight into the nature and extent of the injury caused by the decline in the oil and gas industry" (para. 7.288).

The $\mathrm{AB}$ restated its view on injury attribution:

"Article 4.2(b) does not require that increased imports be the sole cause of serious injury. In addition, we determined in US - Wheat Gluten that the causation requirement of Article 4.2(b) can be met where the serious injury is caused by the interplay of increased imports and other factors. In other words, to meet the causation requirement in Article 4.2(b), it is not necessary to show that increased imports alone- on their own - must be capable of causing serious injury" (para. 209)

The AB upheld the Panel's finding that the ITC failed to follow the non-attribution provision, stating that:

"to fulfill the requirement of Article 4.2(b), last sentence, the competent authorities must establish explicitly, through a reasoned and adequate explanation, that injury caused by factors other than increased imports is not attributed to increased imports. This explanation must be clear and unambiguous. It must not merely imply or suggest an explanation. It must be a straightforward explanation in express terms." (para. 217)

The $\mathrm{AB}$ continued with the following strong language:

"The passage on page I-30 of the USITC Report highlighted by the United States is but a mere assertion that injury caused by other factors is not attributed to increased imports. A mere assertion such as this does not establish explicitly, with a reasoned and adequate explanation, that injury caused by factors other than the increased imports was not attributed to increased imports. This brief assertion in the ITC Report offers no reasoning and no explanation at all, and therefore falls short of what we have earlier described as a reasoned and adequate explanation" (para. 220).

Yet, having pushed the issue this far, it is not entirely clear what the panels and $A B$ are looking for in terms of attribution. The bodies have not specified any method for ensuring nonattribution and have said that a quantitative approach is not required, but are not very constructive in terms of suggesting how the ITC can better assess the injury caused by other factors. Furthermore, since the WTO bodies have determined that imports themselves need not be a cause of serious injury, the entire exercise of apportioning injury to various factors becomes 
semantic. Non-attribution requires the authorities to separate and distinguish the sources of injury but otherwise plays no substantive role in the proceedings and cannot affect the end result. At least with the "substantial cause" requirement of Section 201, the ranking of various injurycausing factors plays a crucial role in the process. So there is a point to a decomposition and non-attribution exercise under U.S. law, while there is no point under WTO law except that it is required by Article 4.2(b) of the Safeguards Agreement.

Before considering a potential resolution to this impasse, the consequences of these rulings should be briefly noted. Although the ITC was found to have erred, USTR was responsible for bringing the safeguard action into conformity with WTO obligations. In two of the four cases, the safeguard trade remedy was lifted in advance of its expiration in order to comply with the WTO rulings. In Lamb, USTR terminated the safeguard remedy eight months before it was set to expire and provided financial adjustment assistance to domestic producers. ${ }^{11}$ In Line Pipe, USTR reached a negotiated settlement with South Korea after the AB report that allowed imports of line pipe to increase in stages and went into effect just seven months before the safeguard measure was set to expire. ${ }^{12}$ In Wheat Gluten, USTR did not terminate the trade remedy after the WTO rulings and the EU retaliated against U.S. exports of corn gluten. Wheat Gluten producers requested an extension of the import quotas before they set to expire, but

11 USTR abandoned the trade remedy not just because the ITC report was not in conformity with Article 4.2(b) of the Safeguard Agreement, but because of several problems relating to the failure to demonstrate "unforeseen developments" as required by Article XIX of the GATT and an inconsistent definition of the domestic industry. See the press release, "Bush Administration Settles Lamb Safeguard Issue with Australia and New Zealand," USTR, August $21,2001$.

12 See the press release, "United States and Korea Resolve WTO Dispute on Line Pipe," USTR, July 29, 2002. 
USTR denied this request in June 2001 and the EU lifted its retaliatory duty. ${ }^{13}$

\section{Economic Framework for Injury Attribution}

To adhere to the injury attribution provisions of the Safeguard Agreement, and even to the "substantial cause" provision of Section 201 more carefully than it has, the ITC must essentially decompose injury into its various underlying causes. As the ITC has failed to produce an acceptable "reasoned" solution to the non-attribution issue, an economic or analytical-based approach may solve the ITC's problem. Unfortunately, as Durling and McCullough (2002, p. 10) note, “Although causation and non-attribution are often the central issues in any trade remedy case, the ITC has developed only very primitive analytical tools to address these crucial issues."

Economic analysis provides a simple framework in which to analyze injury attribution and even develop empirical methods that can quantify injury. Figure 1 sets out the framework for analysis. This figure shows domestic demand (D) in the home country for the product in question, as well as total supply $(\mathrm{S}+\mathrm{M})$ to the market, which is simply the horizontal sum of domestic supply (S) and import supply (the distance between $\mathrm{S}$ and $\mathrm{S}+\mathrm{M}$ ). Total supply intersects domestic demand and determines the market-clearing price $(\mathrm{P})$. At this price $\mathrm{P}$, the quantity supplied by domestic producers is $\mathrm{Q}_{\mathrm{S}}$ and the quantity demanded by domestic consumers is $Q_{D}$, with imports constituting the difference between the two $\left(Q_{D}-Q_{S}\right)$.

This market equilibrium can be disturbed by shifts in domestic demand, domestic supply,

13 See the press release, "Bush Administration Helps Wheat Gluten Industry Restore its Competitiveness," USTR, June 1, 2001. 
and import supply. Each shift has a different effect on the price, imports, and domestic consumption and production. For example, Figure 2 illustrates an outward shift in the import supply curve that shifts total supply from $S+M$ to $S+M$ ' but does not affect the position of the domestic supply curve (S). This shift reduces the equilibrium price and thereby increases domestic consumption, reduces domestic production, and increases imports. The motivation for safeguard trade restrictions is presumably to prevent the domestic industry from being injured by precisely such short-term import supply shocks.

Alternatively, an increase in domestic demand, illustrated in Figure 3, would lead to an increase in imports and even the import market share if - as is likely to be the case - the elasticity of import supply is greater than the elasticity of domestic supply. However, this increase in imports presumably would not be a source of injury to domestic producers because the domestic price and domestic production would also have risen as a result of the demand shift. Conversely, a decline in demand would reduce the price and domestic production, but imports again would not be a source of injury because they too would have fallen in response to the decline in demand. Finally, shifts in domestic supply can alter the market equilibrium. A decrease in domestic supply would push the domestic price higher and draw in additional imports, but the increased imports are a response to the shift in domestic supply, and thus it is hard to view them as an independent cause of injury.

Over any given period, of course, domestic supply, import supply, and domestic demand will be changing at the same time. From the standpoint of the legal requirements of the Safeguards Agreement, the key is to isolate the impact of shifts in import supply when domestic supply and demand are also changing. One way in which changes in import supply might be 
interpreted as having the dominant impact on the market is simply to observe the changes in prices and quantities. In the example considered above, if import supply has shifted to the right, then the price and domestic production should fall while imports and domestic consumption should rise.

Table 2 presents some basic data from the recent Section 201 cases to see if market developments in these cases are consistent with this benchmark. For example, the observed changes in Wheat Gluten market are consistent with an outward shift in import supply: between 1995 and 1997, the domestic price fell, domestic production fell, imports increased, and domestic consumption increased. By contrast, the Lamb case is quite different. In this case, the domestic price rose (and import prices rose substantially) and consumption fell while domestic production declined and imports increased. This set of observations is more consistent with a negative domestic supply shock - such as a reduction in federal subsidies - which results in imports being drawn in as a result of declining domestic production, rather than being an independent, causal factor of injury. ${ }^{14}$ It is easier to find that imports were a cause of injury in the Line Pipe case because imports and consumption increased markedly, although the decline in domestic production was small and the prices of domestic and imported goods move in opposite directions.

The table also considers the Wire Rod case, which was not contested in the WTO. With the exception of the fact that domestic production rose slightly, the characteristics of this case

14 The Lamb case may be one in which the Commission was under political pressure to reach an affirmative finding. Senator Max Baucus of Montana, and an important member of the Senate Finance Committee that oversees the ITC budget, testified before the Commission on behalf of the petitioners. Hansen and Prusa (1997) examine the susceptibility of ITC decision making to political pressure from Congress. 
also appear to be consistent with imports being a source of injury. The Steel cases are more of a challenge. In the case of slab, there does not appear to be any pronounced import surge or decline in domestic production. In hot-rolled products, import penetration increased between 1996 and 1998 , but then fell by 2000 , but there was no reduction in domestic output. The same is true in cold-rolled steel. Hence, the "serious injury" determination was an important part of these cases.

Thus, with the notable exception of the Lamb case and the possible exception of Steel, the basic market indicators - interpreted in the context of the simple economic framework outlined above and illustrated in the Figures 1-3 - are broadly consistent with the ITC rulings. The next step is to use a simple method that provides a quantitative breakdown of the relative importance of shifts in supply, demand, and imports in affecting domestic production. Three alternative methods exist: the econometric approaches of Grossman (1986) and Pindyck and Rotemberg (1987) and the simulation approach of Kelly (1988).

Using the steel industry as an example, Grossman (1986) estimates a reduced-form equation that determines domestic production as a function of the relative price of imports, the relative price of inputs (such as iron and energy), and an indicator of overall demand (industrial production). The parameter estimates indicate the sensitivity of domestic production to the relative price of imports and to other supply and demand factors. The estimated equation can be used for counterfactual analysis and determine the impact of these factors on domestic supply. Using the copper industry as an example, Pindyck and Rotemberg (1987) develop a framework for examining the injurious impact of not just exogenous variation in import supply but also endogenous increases in imports (such as when demand increases). Unlike Grossman, they do 
not employ a model of industry structure, but rather rely on Granger-causality regressions to determine the degree of injury caused by all sources of import variation. ${ }^{15}$

The econometric approach has the advantage of allowing industry-specific cost and demand factors to be incorporated into the analysis. The approach can be used to pose sharp counterfactual questions and address detailed questions of attribution. The problem with the econometric approach is that it introduces a host of contestable issues, first and foremost model specification. In constructing any empirical model, choices must be made about model structure and design and in many cases there is no clear cut way of determining which choices are appropriate and which are inappropriate. In addition, there are questions about which data to use, which time frame to examine, which variables to include, etc. As a result, there will not necessarily be any consensus about which approach is best and different empirical results can emerge from differing approaches. ${ }^{16}$

An alternative, non-econometric approach is set out in the neglected article by Kelly (1988). This model, described more fully in the appendix to this paper, is a simple linear specification of the framework set out in Figure 1 and described above. An attractive feature of the model is the simplicity of its data requirements: all that is required to implement the model is

15 For a comparison of the Grossman and Pindyck and Rotemberg approaches, see Rousslang (1988). In using a specific economic framework to analyze these decisions, of course, one is taking a stand on how to interpret the safeguards law; Sykes (2003) argues that the law is quite vague and often contradictory.

${ }^{16}$ In some cases, there is even the issue of data availability: many of the products considered in Section 201 cases are very narrowly defined. As a result, it is unlikely that sufficient time-series data is available on such products as extruded rubber thread or circular welded carbon quality line pipe. There is also the difficult issue of how to model industry specific policies, such as federal government payments to lamb producers. Durling and McCullough (2002) discuss the reluctance of the ITC to rely on econometric analysis. 
the market data presented in Table 2 and elasticity values for domestic supply and demand and import supply. ${ }^{17}$ In essence, the model decomposes the observed changes in domestic production into shifts in demand, supply, and imports as implied by - and consistent with - those elasticities and the observed changes in the market data.

Table 3 uses the Kelly framework to examine the relative size of demand, supply, and import changes in each of the Section 201 cases considered in this paper. The simplest model is where domestic production and imports are treated as perfect substitutes for one another, an assumption that allows imports to have the greatest impact on domestic production. (The model can be modified to treat them as imperfect substitutes; see the original Kelly article.) The data required by the model is taken from the ITC reports and the elasticities of demand, domestic supply and import supply, ranges for which are typically given in ITC reports. Finally, results are presented using both the domestic price and the import price, since there is sometimes a discrepancy between the two (most notably in Line Pipe, where the domestic price rises but the import price falls).

Table 3 presents the decomposition results. For Wheat Gluten, the results clearly suggest that a shift in import supply was the leading cause of the decline in domestic production. As suggested earlier, of all the cases considered, this particular one appears to be the most unambiguous in terms of imports causing injury. For Lamb, the results clearly point to an adverse shift in domestic supply as generating the decline in domestic production. This is consistent with the termination of federal support payments as inflicting the most harm on

17 In this respect, the approach is somewhat similar to the COMPAS model framework currently used by the ITC to evaluate the imposition of antidumping and countervailing duties. 
producers, with imports playing a rather minor role. ${ }^{18}$ In the Line Pipe case, imports appear to be the dominant cause of injury to domestic producers, even as demand appears to be strong. The discussion in this case hinged on whether declining demand from the oil and gas industry was as responsible for injury as imports, yet it is hard to hold to the declining demand interpretation when the domestic price of line pipe is rising and domestic consumption of pipe is increasing, unless the products are highly differentiated.

In the case of Wire Rod, positive movements in domestic demand and supply more than offset the injury due to imports, but a shift in import supply was a negative factor for the domestic industry. Similarly, in the three specific steel products in which the ITC found injury (slab, hot and cold-rolled steel), imports were a source of injury in each case even though shifts in demand and supply enabled domestic production to increase.

Thus, although the simple decomposition exercise does not tell us much more than is revealed by a simple examination of price and quantity trends, it does at least provide a quantitative breakdown of the implied relative contribution of the factors affecting domestic production. One advantage of the Grossman (1986) econometric approach, however, is that it can separate out various factors responsible for a shift in import supply, such as exchange rate movements, tariff reductions, etc. The Kelly approach does not enable different sources of supply and demand shifts to be separated, but treats them in aggregate.

Still, this type of analysis may help the ITC adhere to the WTO's non-attribution requirements. It may be of less use in the "substantial cause" determination because different distinct factors that shift supply and demand are not separated. For example, if domestic

18 For a detailed analysis of the lamb case, see Horn and Mavroidis (2003). 
production declines 15 percent, five percentage points of which are due to imports and ten percentage points of which are due to declining domestic demand, imports could still be the most important cause of injury if several different factors contribute to the decline in demand. Despite these limitations, the greater use of economic analysis at the ITC can only strengthen the credibility of its decisions.

\section{Conclusions}

To date, the ITC has had difficulty in bringing its safeguard determinations into conformity with the requirements of the WTO's Agreement on Safeguards. This paper proposes that economic analysis, specifically, the Kelly (1988) framework of injury attribution, be employed to enable the ITC to ensure that injury caused by non-import related factors is not attributed to imports. With the exception of the Lamb case, this method reaches findings that are consistent with past ITC safeguard decisions and thus would not impose a significant burden on the agency while allowing it to adhere to the WTO agreement. 


\section{Appendix:}

This appendix briefly presents the Kelly (1988) model that treats domestic and imported good as perfect substitutes. (Kelly also develops an imperfect substitutes model; to the extent that these goods are actually imperfect substitutes for one another, the perfect substitutes model will overstates the impact of imports on the domestic market.) Domestic demand, domestic supply, and import supply are specified in simple linear terms such that:

$$
\begin{aligned}
& D=a+b P \\
& S=c+d P \\
& M=e+f P \\
& D=S+M,
\end{aligned}
$$

where $\mathrm{D}$ is the quantity demanded, $\mathrm{S}$ is the quantity supplied by domestic producers, $\mathrm{M}$ is the quantity of imports, and $\mathrm{P}$ is the market price. Equation (1) is demand, equation (2) is domestic supply, equation (3) is import supply, and equation (4) is a market clearing identity. The parameters a, c, and e are shift parameters for demand, supply, and imports, respectively. Substituting equations (1)-(3) into (4) and solving for P yields:

$$
P=(a-c-e) /(-b+d+f)
$$

Then

$$
S=c+d^{*}(a-c-e) /(-b+d+f)
$$

Totally differentiating equation (6) yields:

$$
\text { ) } S=(M / M)) a+(M / M)) c+(M / M)) d
$$

which states that the change in domestic supply can be decomposed into that due to shifts in demand, shifts in supply, and shifts in imports. Kelly describes how ) a, ) c, and ) d can be 
solved for via Cramer's rule. Substituting the solutions back into (7) and rewriting in terms of elasticities yields:

$$
\begin{aligned}
& \text { ) } \mathrm{S}=(1 / \mathrm{v})\left\{\left[\mathrm{w}_{\mathrm{D}},{ }_{\mathrm{D}}(\mathrm{O}() \mathrm{P} / \mathrm{P})-\right) \mathrm{D} / \mathrm{D}\right) \text { ( ) (change in demand) } \\
& \text { - } \left.\left.\left(0-\mathrm{W}_{\mathrm{M}},{ }_{\mathrm{M}}\right)\left({ }_{\mathrm{D}}\right) \mathrm{P} / \mathrm{P}\right)-\mathrm{)} \mathrm{S} / \mathrm{S}\right) \circledast \text { (change in supply) } \\
& \left.\left.-\mathrm{w}_{\mathrm{D}},{ }_{\mathrm{D}}(\mathrm{O}(\mathrm{)} \mathrm{P} / \mathrm{P})-\mathrm{M} / \mathrm{M}) @ \mathrm{M}\right]\right\} \quad \text { (change in imports) }
\end{aligned}
$$

where $\mathrm{v}=\left(0-\mathrm{w}_{\mathrm{D}}, \mathrm{D}_{\mathrm{D}}-\mathrm{w}_{\mathrm{M}},{ }_{\mathrm{M}}\right)$. In this equation, $\mathrm{w}_{\mathrm{D}}=(\mathrm{S} / \mathrm{D}), \mathrm{w}_{\mathrm{M}}=(\mathrm{M} / \mathrm{D}),{ }_{\mathrm{D}}$ is the elasticity of domestic supply, , $\mathrm{m}$ is the elasticity of import supply, 0 is the elasticity of domestic demand.

The terms ) $\mathrm{P} / \mathrm{P}$, ) $\mathrm{S} / \mathrm{S}$, ) D/D, and ) $\mathrm{M} / \mathrm{M}$ are simply the observed changes in the price, supply, demand, and imports in the period under consideration. 
Figure 1: Market Equilibrium with Imports

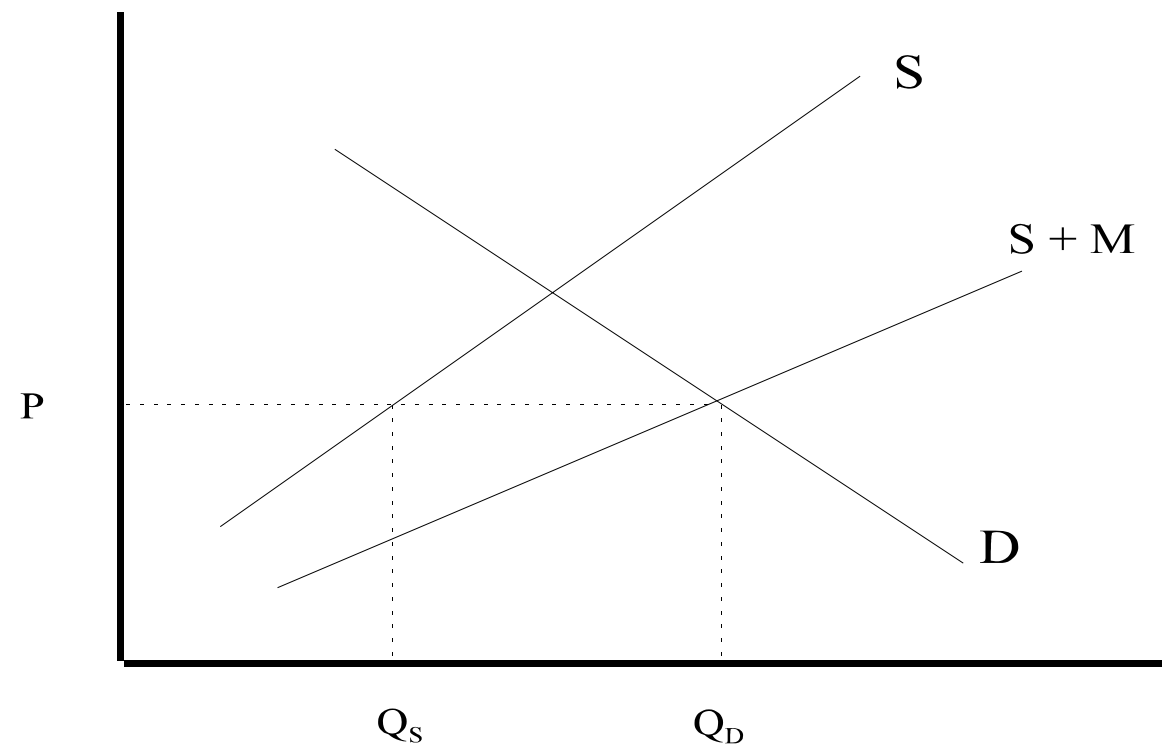

Figure 2: Market Equilibrium with Shift in Import Supply

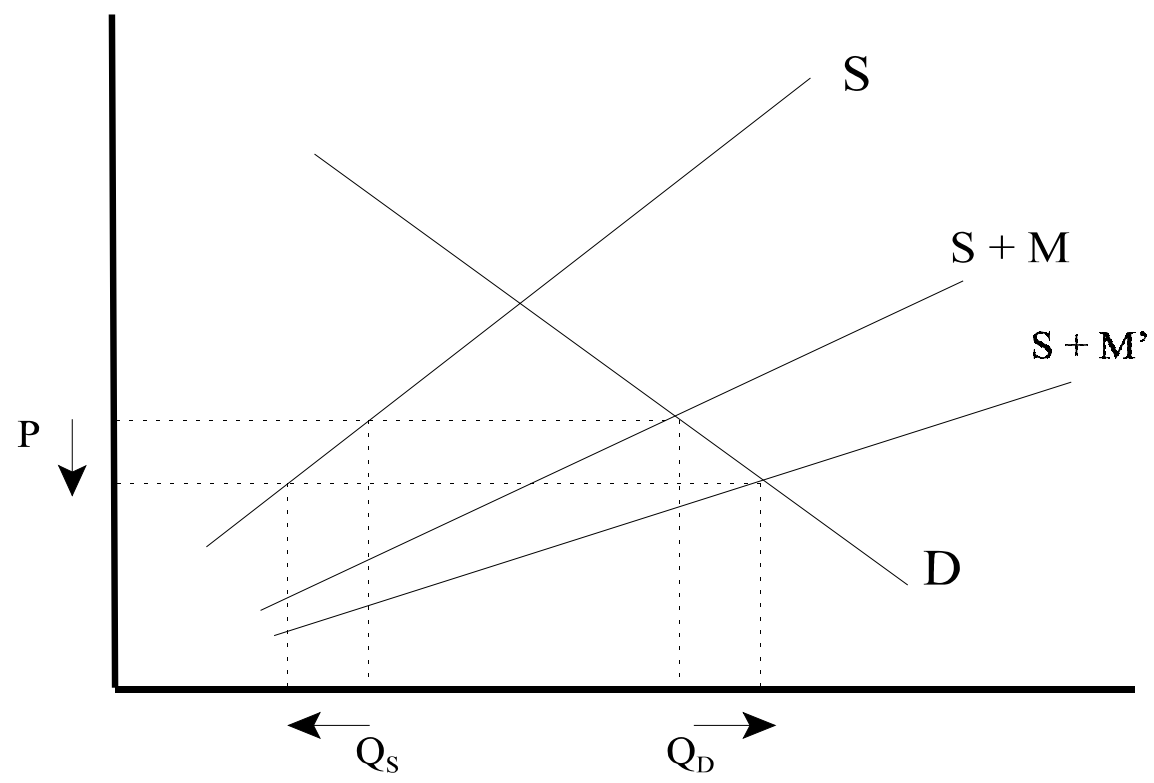


Figure 3: Market Equilibrium with a Shift in Domestic Demand

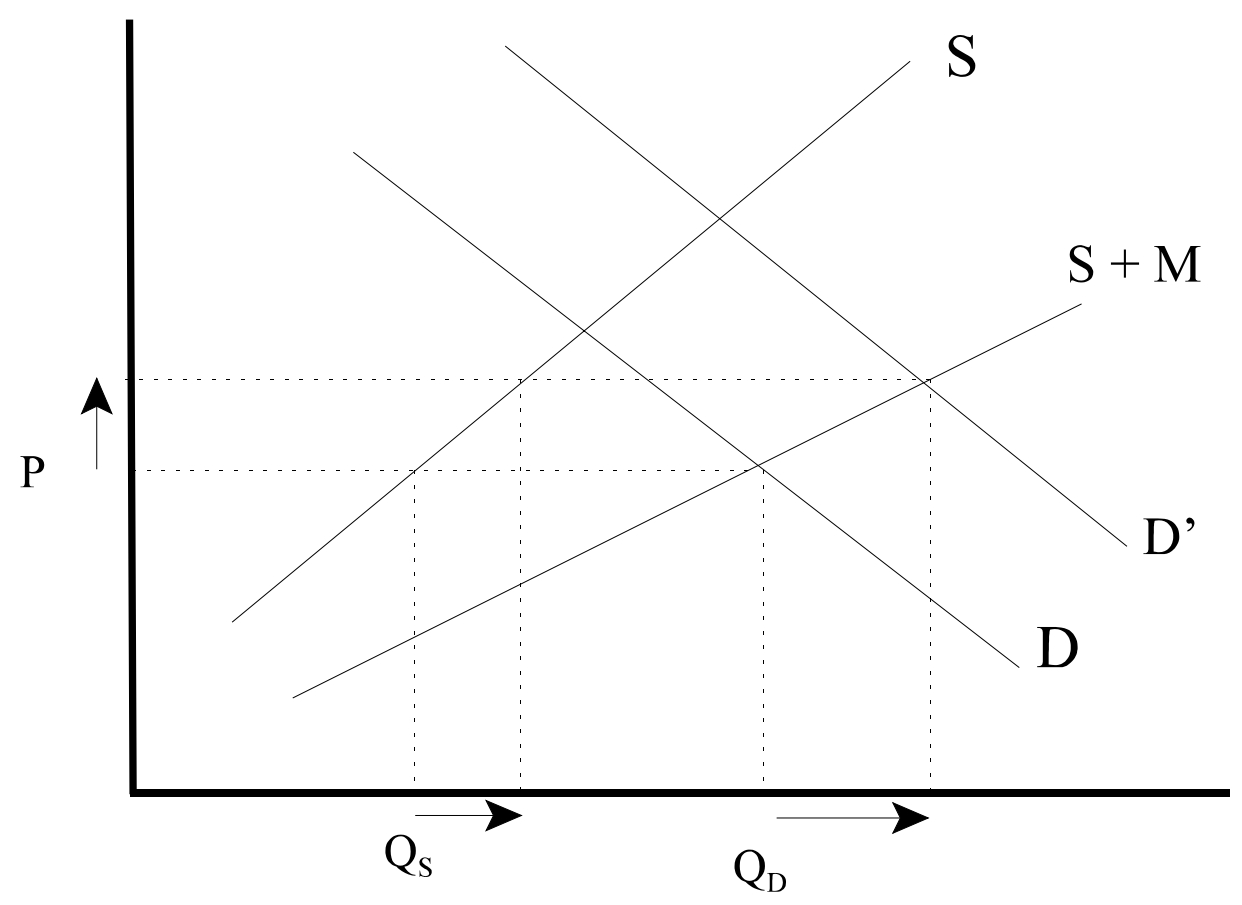


Table 1: Section 201 Cases Since 1995

\begin{tabular}{llcc}
\hline \hline Year & Product & ITC Determination & WTO Challenge? \\
\hline 1995 & Fresh Winter Tomatoes & Terminated & - \\
1996 & Corn Brooms & Affirmative & No \\
1996 & Fresh Tomatoes and Bell Peppers & Negative & - \\
1997 & Wheat Gluten & Affirmative & Yes \\
1998 & Lamb Meat & Affirmative & Yes \\
1999 & Certain Steel Wire Rod & Affirmative (Tie) & No \\
1999 & Circular Welded Line Pipe & Affirmative & Yes \\
2000 & Crabmeat from Swimming Crabs & Negative & - \\
2000 & Extruded Rubber Thread & Negative & - \\
2001 & Steel & Affirmative (16 of 33 & Yes \\
\hline \hline
\end{tabular}

Source: U.S. International Trade Commission. 
Table 2: Selected Data from Section 201 Cases

A. Wheat Gluten

\begin{tabular}{lccc}
\hline \hline & 1995 & 1997 & $\begin{array}{c}\text { Percentage } \\
\text { Change }\end{array}$ \\
\hline Consumption & 255.5 & 294.2 & $15.1 \%$ \\
Domestic Production & 127.5 & 117.1 & $-8.2 \%$ \\
Imports & 128 & 177.1 & $38.4 \%$ \\
& & & -- \\
Import Market Share (percent) & 50.1 & 60.2 & $-10.3 \%$ \\
& & & $-15.2 \%$ \\
Unit Value - Domestic & $\$ 0.68$ & $\$ 0.61$ & $\$ 0.56$ \\
Unit Value - Imports & $\$ 0.66$ & & \\
\hline \hline
\end{tabular}

Source: USITC (1998), Table C-1. Units: thousands of pounds.

B. Lamb Meat

\begin{tabular}{lccc}
\hline \hline & 1995 & 1997 & $\begin{array}{c}\text { Percentage } \\
\text { Change }\end{array}$ \\
\hline Consumption & 320.8 & 306.6 & $-4.4 \%$ \\
Domestic Production & 277.5 & 246.2 & $-11.3 \%$ \\
Imports & 43.3 & 60.4 & $39.5 \%$ \\
& & & -- \\
Import Market Share (percent) & 13.5 & 19.7 & \\
& & & $4.9 \%$ \\
Unit Value - Domestic & $\$ 1.62$ & $\$ 1.70$ & $24.6 \%$ \\
Unit Value - Imports & $\$ 1.83$ & $\$ 2.28$ & \\
\hline \hline
\end{tabular}

Source: USITC (1999a), Table C-1. Units: thousands of pounds.

C. Line Pipe 
$-32-$

\begin{tabular}{lccc}
\hline \hline & 1996 & 1998 & $\begin{array}{c}\text { Percentage } \\
\text { Change }\end{array}$ \\
\hline Consumption & 791.5 & 971.4 & $22.7 \%$ \\
Domestic Production & 664.9 & 640.2 & $-3.7 \%$ \\
Imports & 126.6 & 331.2 & $161.6 \%$ \\
& & & \\
Import Market Share (percent) & 16.0 & 34.1 & -- \\
& & & $3.7 \%$ \\
Unit Value - Domestic & $\$ 486$ & $\$ 504$ & $-5.6 \%$ \\
Unit Value - Imports & $\$ 483$ & $\$ 456$ & \\
\hline \hline
\end{tabular}

Source: USITC (1999c), Table C-1. Units: tons.

D. Certain Steel Wire Rod

\begin{tabular}{lccc}
\hline \hline & 1996 & 1998 & $\begin{array}{c}\text { Percentage } \\
\text { Change }\end{array}$ \\
\hline Consumption & 7.6 & 8.3 & $8.7 \%$ \\
Domestic Production & 5.5 & 5.7 & $3.8 \%$ \\
Imports & 2.1 & 2.5 & $21.8 \%$ \\
& & & \\
Import Market Share (percent) & 27.4 & 30.7 & -- \\
& & & $-6.1 \%$ \\
Unit Value - Domestic & $\$ 350$ & $\$ 340$ & $-6.3 \%$ \\
Unit Value - Imports & $\$ 365$ & $\$ 342$ & \\
\hline \hline
\end{tabular}

Source: USITC (1999b), Table C-1. Units: millions of tons. 


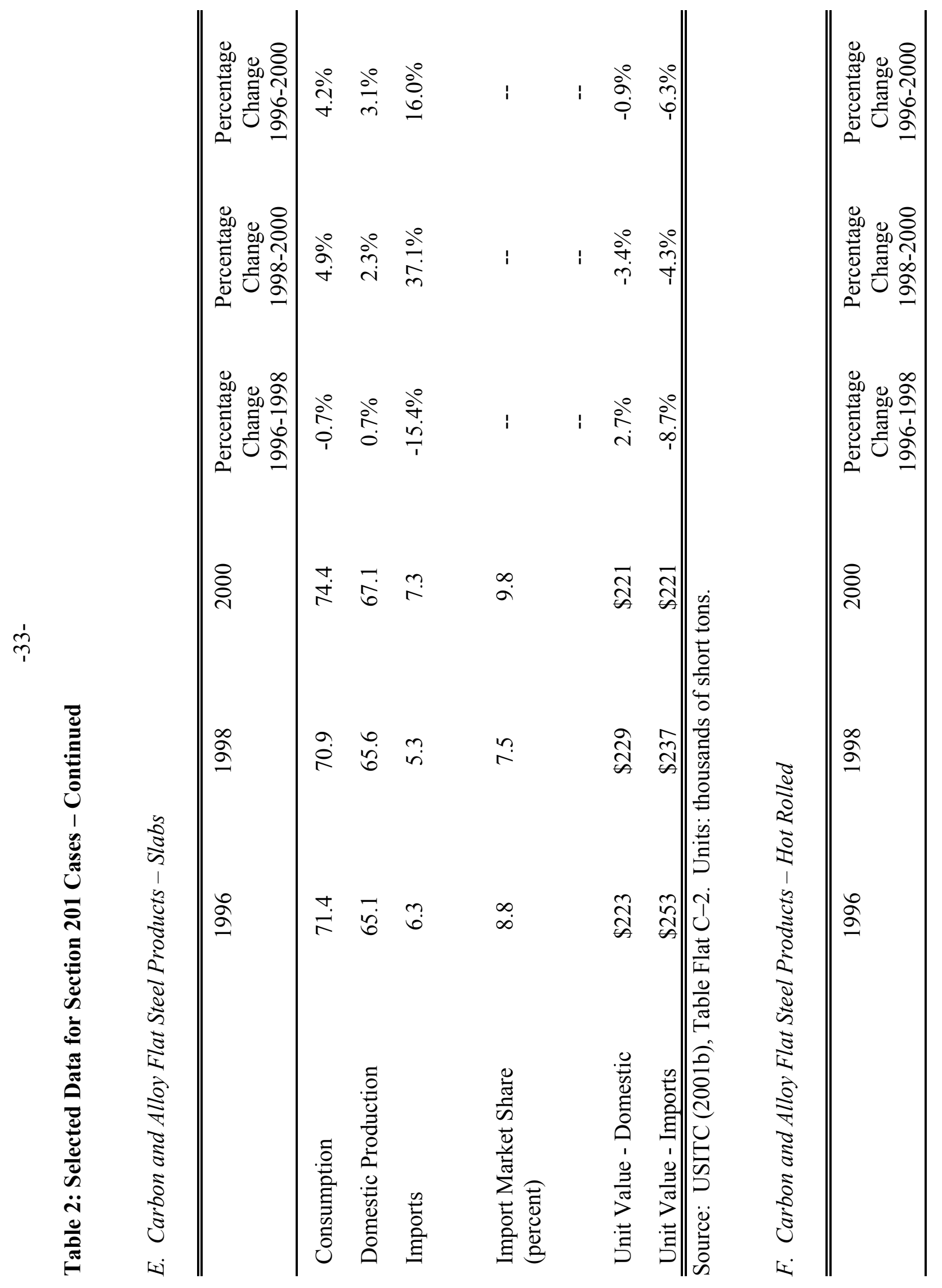




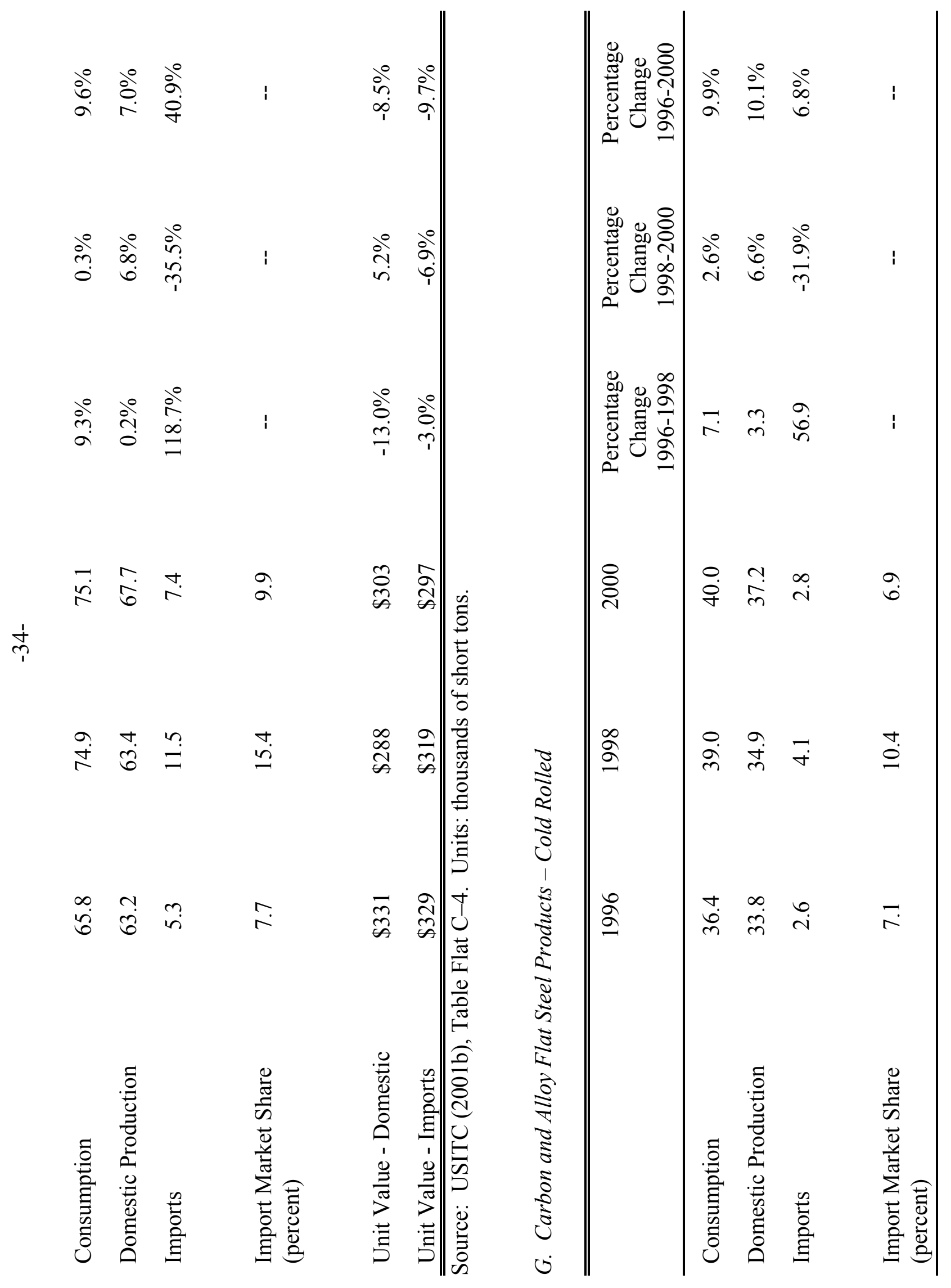




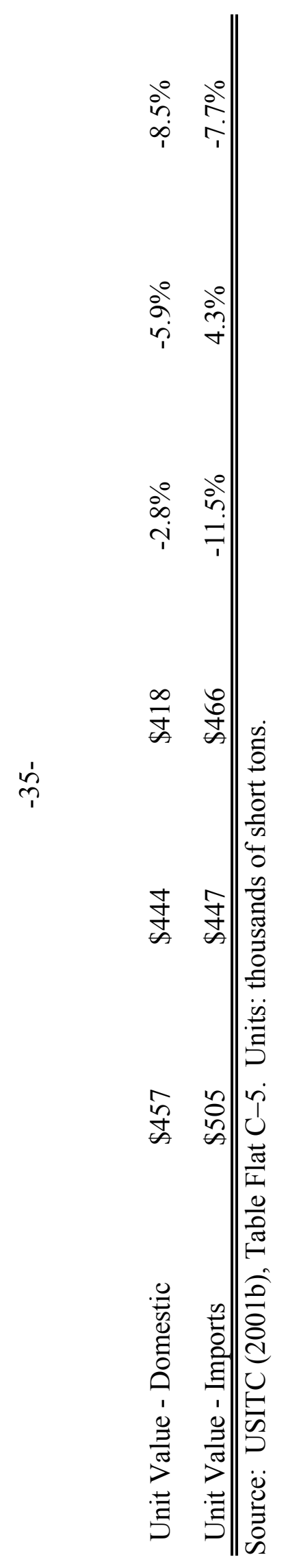


Table 3: Attribution of Injury in Selected Section 201 Cases

\section{A. Wheat Guten}

\begin{tabular}{ccccc}
\hline & $\begin{array}{c}\text { Percentage Change } \\
\text { in Domestic } \\
\text { Production }\end{array}$ & $\begin{array}{c}\text { Due to Demand } \\
\text { Shift }\end{array}$ & $\begin{array}{c}\text { Due to Supply } \\
\text { Shift }\end{array}$ & $\begin{array}{c}\text { Due to Import } \\
\text { Shift }\end{array}$ \\
$\begin{array}{c}\text { Domestic } \\
\text { Price }\end{array}$ & -8.2 & 1.6 & 1.8 & -11.6 \\
$\begin{array}{c}\text { Import } \\
\text { Price }\end{array}$ & -8.2 & 0.1 & 5.8 & -14 \\
\hline
\end{tabular}

Assumptions: The ITC report had no information on elasticity values. The assumed values are: elasticity of demand $(0)=-0.75$, elasticity of domestic supply $()=$,1.0 , elasticity of import supply $(()=3.0$.

\section{B. Lamb}

\begin{tabular}{ccccc}
\hline & $\begin{array}{c}\text { Percentage Change } \\
\text { in Domestic } \\
\text { Production }\end{array}$ & $\begin{array}{c}\text { Due to Demand } \\
\text { Shift }\end{array}$ & $\begin{array}{c}\text { Due to Supply } \\
\text { Shift }\end{array}$ & $\begin{array}{c}\text { Due to Import } \\
\text { Shift }\end{array}$ \\
$\begin{array}{c}\text { Domestic } \\
\text { Price }\end{array}$ & -11.3 & 0.2 & -10 & -1.4 \\
$\begin{array}{c}\text { Import } \\
\text { Price }\end{array}$ & -11.3 & 8.8 & -22.2 & 2 \\
\hline
\end{tabular}

Assumptions: The ITC (1999a, pp. II-70, II-62) reports the three year elasticity of demand as ranging from -0.75 to -1.25 and the three year elasticity of domestic supply as 0.7 to 1.3 . The assumed values are: elasticity of demand $(0)=-1.0$, elasticity of domestic supply $()=$,1.0 , elasticity of import supply $(()=3.0$

\section{Line Pipe}

$\begin{array}{cccc}\begin{array}{c}\text { Percentage Change } \\ \text { in Domestic } \\ \text { Production }\end{array} & \begin{array}{c}\text { Due to Demand } \\ \text { Shift }\end{array} & \begin{array}{c}\text { Due to Supply } \\ \text { Shift }\end{array} & \begin{array}{c}\text { Due to Import } \\ \text { Shift }\end{array} \\ -3.7 & 16.5 & -4.1 & -16.1\end{array}$

Domestic
Price

Price 
$\begin{array}{lllll}\text { Import } & -3.7 & 13.3 & 2 & -19.1\end{array}$

Price

Assumptions: The ITC (1999c, pp. II-44, II-42) reports that demand is "lower degree of price sensitivity" and "moderate to high" price sensitivity of supply. The assumed values are: elasticity of demand $(0)=-0.5$, elasticity of domestic supply $()=$,1.5 , elasticity of import supply $(()=3.0$

\section{Certain Steel Wire Rod}

\begin{tabular}{ccccc}
\hline & $\begin{array}{c}\text { Percentage Change } \\
\text { in Domestic } \\
\text { Production }\end{array}$ & $\begin{array}{c}\text { Due to Demand } \\
\text { Shift }\end{array}$ & $\begin{array}{c}\text { Due to Supply } \\
\text { Shift }\end{array}$ & $\begin{array}{c}\text { Due to Import } \\
\text { Shift }\end{array}$ \\
$\begin{array}{c}\text { Domestic } \\
\text { Price }\end{array}$ & 3.6 & 4.6 & 5.1 & -6.1 \\
$\begin{array}{c}\text { Import } \\
\text { Price }\end{array}$ & 3.6 & 2.5 & 9.5 & -8.4 \\
\hline
\end{tabular}

Assumptions: The ITC (1999b, pp. II-48) reports inelastic demand ranging from -0.5 to -0.75 and an elasticity of domestic supply as 2.0 to 4.0 . The assumed values are: elasticity of demand $(0)=-0.75$, elasticity of domestic supply $()=$,3.0 , elasticity of import supply $(()=3.0$

\section{E. Steel Products - Slab (1996-2000)}

\begin{tabular}{ccccc}
\hline & $\begin{array}{c}\text { Percentage Change } \\
\text { in Domestic } \\
\text { Production }\end{array}$ & $\begin{array}{c}\text { Due to Demand } \\
\text { Shift }\end{array}$ & $\begin{array}{c}\text { Due to Supply } \\
\text { Shift }\end{array}$ & $\begin{array}{c}\text { Due to Import } \\
\text { Shift }\end{array}$ \\
$\begin{array}{c}\text { Domestic } \\
\text { Price }\end{array}$ & +2.3 & +2.9 & +3.1 & -3.4 \\
$\begin{array}{c}\text { Import } \\
\text { Price }\end{array}$ & +2.3 & +1.4 & +5.7 & -4.9 \\
\hline
\end{tabular}

Assumptions: The ITC (2001b, p. FLAT-60) reports inelastic demand ranging from -0.4 to -0.6 and an elasticity of domestic supply from 3.0 to 6.0. The assumed values are: elasticity of demand $(0)=-0.5$, elasticity of domestic supply $()=$,5.0 , elasticity of import supply $(()=5.0$ 


\begin{tabular}{ccccc}
\hline & $\begin{array}{c}\text { Percentage Change } \\
\text { in Domestic } \\
\text { Production }\end{array}$ & $\begin{array}{c}\text { Due to Demand } \\
\text { Shift }\end{array}$ & $\begin{array}{c}\text { Due to Supply } \\
\text { Shift }\end{array}$ & $\begin{array}{c}\text { Due to Import } \\
\text { Shift }\end{array}$ \\
$\begin{array}{c}\text { Domestic } \\
\text { Price }\end{array}$ & +7.1 & +4.9 & +7.9 & -5.8 \\
$\begin{array}{c}\text { Import } \\
\text { Price }\end{array}$ & +7.1 & +4.3 & +8.9 & -6.2 \\
\hline
\end{tabular}

Assumptions: The ITC (2001b, p. FLAT-60) reports inelastic demand ranging from -0.4 to -0.6 and an elasticity of domestic supply from 3.0 to 6.0. The assumed values are: elasticity of demand $(0)=-0.5$, elasticity of domestic supply $()=$,5.0 , elasticity of import supply $(()=5.0$

G. Steel Products - Cold Rolled (1996-2000)

\begin{tabular}{ccccc}
\hline & $\begin{array}{c}\text { Percentage Change } \\
\text { in Domestic } \\
\text { Production }\end{array}$ & $\begin{array}{c}\text { Due to Demand } \\
\text { Shift }\end{array}$ & $\begin{array}{c}\text { Due to Supply } \\
\text { Shift }\end{array}$ & $\begin{array}{c}\text { Due to Import } \\
\text { Shift }\end{array}$ \\
$\begin{array}{c}\text { Domestic } \\
\text { Price }\end{array}$ & +10.1 & +5.1 & +8.2 & -3.2 \\
$\begin{array}{c}\text { Import } \\
\text { Price }\end{array}$ & +10.1 & +5.4 & +7.6 & -3.0 \\
\hline
\end{tabular}

Assumptions: The ITC (2001b, p. FLAT-60) reports inelastic demand ranging from -0.4 to -0.6 and an elasticity of domestic supply from 3.0 to 6.0. The assumed values are: elasticity of demand $(0)=-0.5$, elasticity of domestic supply $()=$,5.0 , elasticity of import supply $(()=5.0$ 


\section{References}

Bown, Chad P. "Why Are Safeguard Measures under the WTO So Unpopular?" World Trade Review 1 (March 2002): 47-62.

Durling, James P., and Matthew P. McCullough. "Teaching Old Laws New Tricks: The Legal Obligation of Non-Attribution and the Need for Economic Rigor in Injury Analyses under U.S. Trade Law." In James Harrigan (eds.), Handbook of International Trade. New York: Blackwell, 2003.

Hansen, Wendy, and Thomas Prusa. "Economics and Politics: An Empirical Analysis of ITC Decision-making," Review of International Economics 5 (1997): 230-45.

Hoekman, Bernard M., and Michel M. Kostecki. The Political Economy of the World Trading System: The WTO and Beyond. 2 $2^{\text {nd }}$ edition. New York: Oxford University Press, 2001.

Grossman, Gene M. "Imports as a Cause of Injury: The Case of the U.S. Steel Industry." Journal of International Economics 20 (May 1986): 201-23.

Horn, Henrik, and Petros C. Mavroidis. "United States - Safeguard Measures on Imports of Fresh, Chilled or Frozen Lamb Meat from New Zealand and Australia: What Should be Required of a Safeguard Investigation?" Prepared for the American Law Institute Project on "Principles of Trade Law: The WTO,” March 17, 2003.

Kaplan, Seth. "Injury and Causation in USITC Antidumping Determinations: Five Recent Approaches.” In P. K. M. Tharakan (ed.), Policy Implications of Antidumping Measures. Amsterdam: North Holland, 1991.

Kelly, Kenneth. "The Analysis of Causality in Escape Clause Cases." Journal of Industrial Economics 37 (December 1988): 187-207.

Pindyck, Robert S., and Julio J. Rotemberg. "Are Imports to Blame? Attribution of Injury under the 1974 Trade Act.” Journal of Law and Economics 30 (April 1987): 101-22.

Rousslang, Donald J. "Import Injury in U.S. Trade Law: An Economic View." International Review of Law and Economics 8 (1988): 177-182.

Sykes, Alan O. "Protectionism as a 'Safeguard': A Positive Analysis of the GATT 'Escape Clause' with Normative Speculations." University of Chicago Law Review 58 (1991) 255 .

Sykes, Alan O. "The Safeguards Mess." Paper presented at the Dartmouth-Tuck Forum on International Trade and Business, Washington, D.C., May 2003.

U.S. House of Representatives. Committee on Ways and Means. Overview and Compilation of U.S. Trade Statutes. Washington, D.C.: GPO, 1997. 
U.S. International Trade Commission. Wheat Gluten. Publication No. 3088. Washington, D.C.: USITC, March 1998.

U.S. International Trade Commission. Lamb Meat. Publication No. 3176. Washington, D.C.: USITC, April 1999. (A)

U.S. International Trade Commission. Certain Steel Wire Rod. Publication No. 3207.

Washington, D.C.: USITC, July 1999. (B)

U.S. International Trade Commission. Circular Welded Carbon Quality Line Pipe. Publication No. 3261. Washington, D.C.: USITC, December 1999. (C)

U.S. International Trade Commission. Wheat Gluten: Consistency Determination. Publication No. 3423. Washington, D.C.: USITC, May 2001. (A)

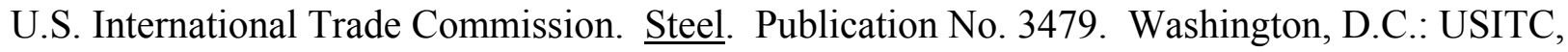
December 2001. (B)

World Trade Organization. "United States - Safeguard Measures on Imports of Fresh, Chilled or Frozen Lamb Meat from New Zealand and Australia." Report of the Panel. WT/DS177/R. Geneva: WTO, December 21, 2000.

World Trade Organization. "United States - Safeguard Measures on Imports of Fresh, Chilled or Frozen Lamb Meat from New Zealand and Australia." Report of the Appellate Body. WT/DS177/AB/R. Geneva: WTO, May 1, 2001.

World Trade Organization. "United States - Definitive Safeguard Measures on Imports of Wheat Gluten From the European Communities." Report of the Appellate Body. WT/DS166/AB/R, December 22, 2000.

World Trade Organization. "United States - Definitive Safeguard Measures on Imports of Wheat Gluten From the European Communities." Report of the Panel. WT/DS166//R, July 31, 2000 .

World Trade Organization. "United States - Definitive Safeguard Measures on Imports of Circular Welded Carbon Quality Line Pipe from Korea." Report of the Panel. WT/DS202/R, October 29, 2001.

World Trade Organization. "United States - Definitive Safeguard Measures on Imports of Circular Welded Carbon Quality Line Pipe from Korea." Report of the Appellate Body. WT/DS202/AB/R, February 15, 2002. 